\title{
New observations on Permocalculus gosaviensis SCHLAGINTWEIT, 1991 (calcareous alga) from the Upper Cretaceous of the Northern Calcareous Alps (Gosau Group, Austria)
}

\author{
Felix SCHLAGINTWEIT \\ Lerchenauerstr. 167, 80935 München, Germany
}

Received March 2010; accepted June 2010

Available online 7 August 2010

DOI: $10.5038 / 1937-8602.55 .2 .5$

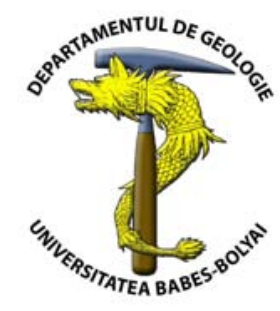

\begin{abstract}
New thin-sections from the Upper Cretaceous Gosau Group of Brandenberg, Tyrol, Austria, yielded well-preserved specimens of the calcareous alga Permocalculus gosaviensis SCHLAGINTWEIT. Microfacies are foraminiferal-algal wackestones; stratigraphy is Upper Turonian (? Lower Coniacian). It is shown that the original description was based on oblique sections leading to the incorrect assumption of a piryform segment morphology. Instead, P. gosaviensis is a representative of Permocalculus of the group with constrictions/swellings along the segments (waxing-and-waning type). Permocalculus nikolapantici RADOIČIĆ from the Upper Turonian of Serbia is considered a junior synonym of Permocalculus gosaviensis SCHLAGINTWEIT.
\end{abstract}

Key words: Calcareous algae, systematics, micropalaeontology, Upper Cretaceous, Gosau Group, Northern Calcareous Alps, Austria.

\section{INTRODUCTION}

In 1991, Schlagintweit described the new species Permocalculus gosaviensis from the Late Turonian (? Early Coniacian) Lower Gosau Subgroup of the Strobl Weissenbach Valley, near Lake Wolfgang (Salzkammergut area, Austria) predominantly based on transverse and oblique sections assuming a piryform (club-shaped) thallus morphology. A transverse section has been chosen as holotype. New thin-sections from the southern part of the Lower Gosau Group of Brandenberg yielded well-preserved specimens of Permocalculus gosaviensis evidencing new thallus details that necessitate a redescription and emendation of the species.

\section{MATERIAL AND SAMPLE LOCALITIES}

The studied material comes from thin sections of the following localities of the southern part of the Gosau Group of Brandenberg, Tyrol, Austria (Fig. 1):

- thin section 5495-10 and 5495-12: Upper Turonian-Lower Coniacian, profile Unterberg 1. Microfacies: foraminiferanalgal wackestones with scattered debris of corals/sponges for 5495-10; microfacies of 5495-12 is the same as for 19995-19 (see below). Foraminifera: Miliolids (Quinqueloculina sp., Vidalina hispanica SCHLUMBERGER), cuneolinids, Montcharmontia apenninica (DE CASTRO), Tetrataxiella? floriforma SCHLAGINTWEIT \& SANDERS, Nezzazatinella picardi (HENSON); calcareous algae: Milanovicella hammudai (RADOIČIĆ). Incertae sedis: Pienina oblonga BORZA \& MISIK. For the lithostratigraphic column of the Unterberg section (see Sanders, 1998; Fig. 7A).

- thin section 19995-19: Upper Turonian-Lower Coniacian, profile Unterberg 2. Floatstones with debris of corals. Foraminifera: Cuneolinids. Calcareous algae: Milanovicella hammudai (RADOIČIĆ), Cylindroporella? aff. kochanskyae RADOIČIĆ. For the lithostratigraphic column of the Unterberg section (see Sanders, 1998; Fig. 7A).

- thin section 16795-7 and 16795-9: Upper Turonian-Lower Coniacian, profile Haidach 1. Bioclastic wackestones. Foraminifera: Gendrotella rugoretis (GENDROT), miliolids (Quinqueloculina sp., Vidalina hispanica SCHLUMBERGER), cuneolinids, dictyopsellids, Tetrataxiella? floriforma SCHLAGINTWEIT \& SANDERS. Calcareous algae: scattered debris of corallinaceans, Polystrata alba (PFENDER), Gosavisiphon paucimedullaris (SCHLAGINTWEIT \& EBLI), Acicularia? aff. magnapora KUSS, Milanovicella hammudai (RADOIČIĆ). For the lithostratigraphic column of the Haidach section (see Sanders, 1998; Figs. 10, 12).

- Thin section 17995-22: Upper Turonian-Lower Coniacian, profile Unterstube. Foraminiferan-algal wackestones. Foraminifera: Gendrotella rugoretis (GENDROT), miliolids (Quinqueloculina sp., Vidalina hispanica SCHLUMBERGER), cuneolinids, dictyopsellids, Tetrataxiella? floriforma SCHLAGINTWEIT \& SANDERS; calcareous algae: scattered debris of corallinaceans, Neomeris sp., Terquemella? sp., Acicularia? aff. magnapora KUSS. 


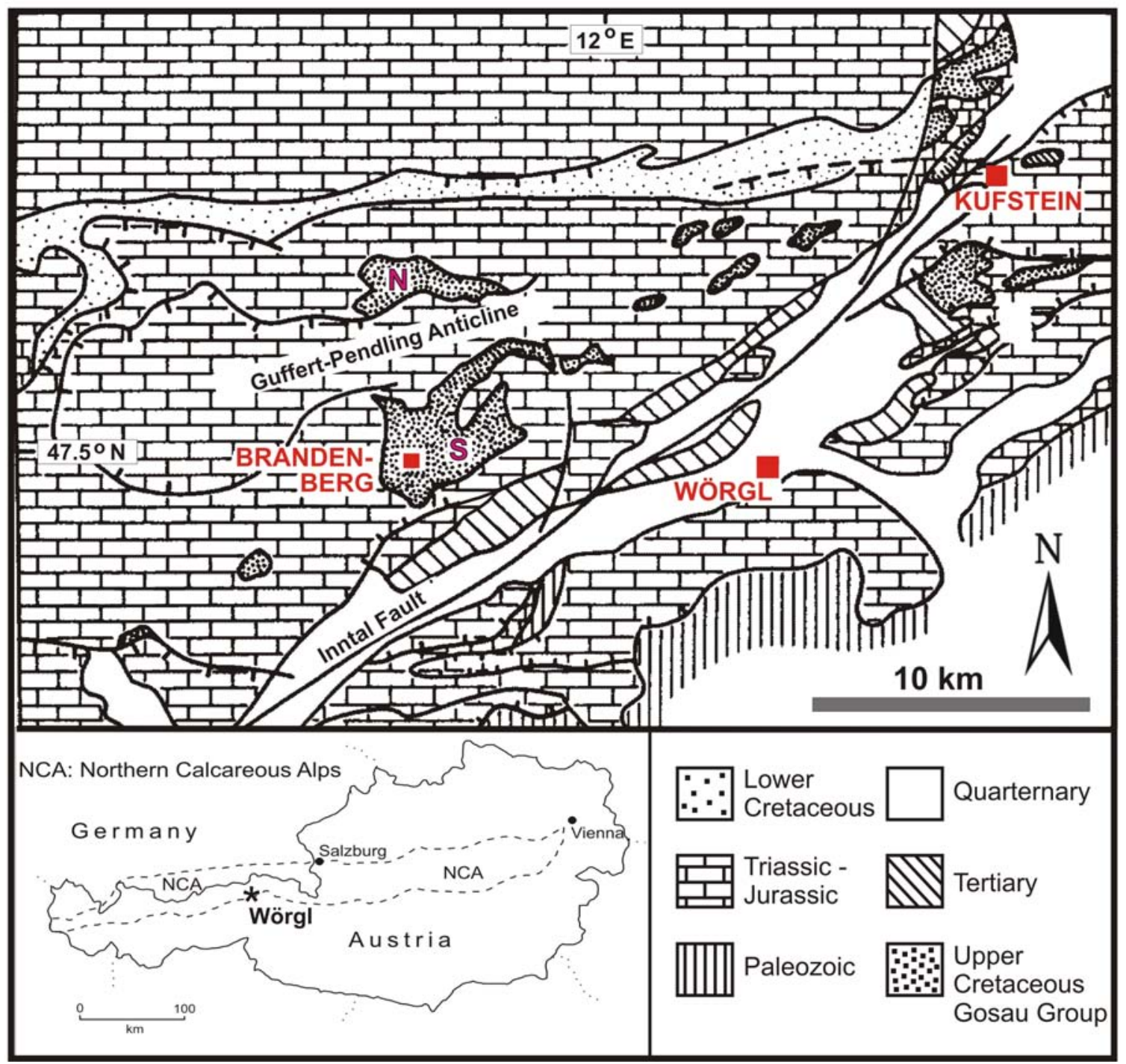

Fig. 1. Simplified geological map and location of the Gosau Group of Brandenberg, Tyrol, Austria (after Sanders, 1998). N=northern part, $S=$ southern part. Samples with Permocalculus gosaviensis SCHLAGINTWEIT are from the southern part.

\section{MICROPALAEONTOLOGICAL DATA}

Genus Permocalculus ELLIOTT, 1955

Permocalculus gosaviensis SCHLAGINTWEIT, 1991

(Pl. I, Figs. 1-14, Pl. II, Figs. 1-2, 3 pars, 4-11)

1991 Permocalculus gosaviensis, n. sp. - Schlagintweit, Pl. II Figs. 1-17.

2004 Permocalculus nikolapantici n. sp. - Radoičić, Pl. I-IV.

Emended diagnosis: Thallus consisting of (sub)cylindrical segments with or without constrictions (waxing-and-waning type), may be branching. Medullary zone mostly poorly calcified, occupying approximately the half of the segment diameter. Medullary filaments subparallel, thicker than cortical filaments. Rather large ovoidal micritic bodies within the subcortical zone (? reproductive organs).

Description: The segments consist of sparry calcite and are (sub)cylindrical in shape, commonly showing constrictions, so-called waxing-and-waning morphology sensu Elliott (1959) (Pl. I, Figs. 4, 5). The constrictions account for an appearance of superimposed barrels; towards the segment endings, the diameter is diminishing (Pl. I, Fig. 10). One segment shows branching at its tip generating two short segments of unequal size (Pl. I, Studia UBB, Geologia, 2010, 55 (2), 59 - 65
Fig. 5); the branching angle is about 45 degree. Segment cross-sections are roughly circular (Pl. I, Fig. 14, Pl. II, Figs. 7, 8, and 10). Segments are differentiated into a central medullary zone and a cortical zone. Calcification is variable; occasionally the medullary zone is preserved (e.g., Pl. II, Fig. 4, 11) indicating that at least a part of it was calcified, but usually is represented by a sedimentfilled hollow (Pl. II, Figs. 7, 10). Sometimes, also the subcortical zones are no longer preserved (Pl. I, Figs. 5, 6). Medullary filaments are subparallel (Pl. I, Fig. 9, Pl. II, Fig. 4). From here, cortical filaments arise by curving and branching. Medullary filaments thicker then the cortical ones; the latter show a terminal widening towards the segment surface. In tangential sections, the cortical filaments show a regular alternating position (Pl. I, Fig. 2, Pl. II, Fig. 6). Ovoid micrite-filled bodies (diameter about $0.1 \mathrm{~mm}$ ) within the subcortical may be interpreted as reproductive organs (Pl. I, Figs. 7, 8). In transverse sections with decalcified medullary zone, the outline towards the cortical zone is irregular (Pl. I, Fig. 14, Pl. II, Fig. 7, Fig. 9, right specimen); this may be caused by the supposed reproductory organs or also to swellings at the branching of subcortical filaments (Pl. I, Fig. 3).

Dimensions: see Table 1. 
Table 1. Dimensions of Permocalculus gosaviensis SCHLAGINTWEIT from the Upper Turonian-Lower Coniacian of the Northern Calcareous Alps and NW Serbia (Radoičić, $2004=$ Permocalculus nikolapantici).

\begin{tabular}{|l|c|c|}
\hline & $\begin{array}{c}\text { Upper Turonian -Lower Coniacian } \\
\text { (Northern Calcareous Alps) }\end{array}$ & $\begin{array}{c}\text { Upper Turonian } \\
\text { (NW Serbia) }\end{array}$ \\
\hline $\begin{array}{l}\text { Outer segment diameter } \\
(\mathrm{D} \text { in } \mathrm{mm})\end{array}$ & $0.3-1.4$, mean $=0.58, \mathrm{n}=45$ & $\begin{array}{c}0.72-0.96 \text { short barrel-like segments } \\
0.96-1.35 \text { large segments } \\
0.4-0.48 \text { waxing-and-waning segments }\end{array}$ \\
\hline Diameter medullary zone $(\mathrm{d}$ in $\mathrm{mm})$ & $0.15-0.64$, mean $=0.29, \mathrm{n}=25$ & $0.32-0.4$ \\
\hline $\mathrm{d} / \mathrm{D}$ & $0.44-0.7$, mean $=0.54, \mathrm{n}=25$ & - \\
\hline Diameter of medullary filaments $(\mathrm{mm})$ & $0.015-0.03$ & - \\
\hline Diameter of cortical filaments $(\mathrm{mm})$ & $0.01-0.04$ & $0.032-0.04$ \\
\hline
\end{tabular}

Remarks: Some longitudinal sections of Permocalculus gosaviensis clearly display what Elliott (1959) designated as waxing-and-waning (or moniliform) type with alternating constrictions along the axis. This special morphology is known from the Upper Permian Permocalculus fragilis PIA, the Lower Cretaceous Permocalculus ampullaceus ELLIOTT (Roux and Deloffre, 1990) and the Upper Cretaceous Permocalculus gosaviensis SCHLAGINTWEIT. The minute reconstruction provided by Kochansky-Devidé and Slisković (1968) has shown that within the same thallus of a single species there can be both more cylindrical parts (preferentially at the base) and those with regular constrictions. This had lead to the creation of ambiguous species (see Roux and Deloffre, 1990 for details). On the other side, there are also sections of Permocalculus species that show constrictions but have not been described as possessing moniliform segments, e.g., Permocalculus inopinatus (Elliott, 1956; Fig. 1A) or Permocalculus irenae (Elliott, 1958; Pl. 47, Fig. 3, Pl. 48, Fig. 2). However, only a few illustrations have been provided in the original descriptions for both species. With respect to Permocalculus inopinatus, we can state that the constrictions of the segments are distinctly less pronounced, less regular, and more widely spaced. In the case of segment breakage, this would not lead to barrel-shaped segments. In any case, there seem to be transitional forms of segments with less pronounced constrictions and also with well-developed waxing-and-waning morphology. Therefore, a passably species identification needs abundant material, whereas single sections are hardly if any assignable. Common practice often seems to be to give a species name simply because of the known or inferred stratigraphic position of the studied samples. In this respect, a special reference is made to Permocalculus inopinatus from the Barremian Aptian of the Middle East (Elliott, 1956) and Permocalculus irenae from the Cenomanian of the Middle East (Elliott, 1958).

In 2004, Radoičić described the new species Permocalculus nikolapantici from the Turonian of Serbia with typically waxing-and-waning type segments. It should be mentioned that Radoičić differentiated morphologically and dimensionally (range from 0.4 to $1.35 \mathrm{~mm}$ ) between large segments, barrel-like segments, and segments of waxing-and-waning units. The short barrel-like segments, however, are the simple product of broken waxing-andwaning parts. In any case, the segment dimensions of $P$. gosaviensis and $P$. nikolapantici are comparable. Some illustrations show striking analogies, for instance the fragment with preserved medullary filaments of Radoičić (2004, Pl. III, Fig. 10) and that one from P. gosaviensis shown in Pl. II, Fig. 4. Furthermore, Radoičić (2004, p. 241) remarks that $P$. nikolapantici differs "much from"...
Permocalculus gosaviensis "by very variable morphology", but noted also that "both species occur in a similar foraminiferal association". From the new material observed it is evident, that the morphology of $P$. gosaviensis was erroneously interpreted as piryform. In fact, oblique sections of broken barrel-shaped segments of the waxing-andwaning-type may pretend such a morphology. Therefore, the species Permocalculus nikolapantici RADOIČIĆ is regarded as a junior synonym of Permocalculus gosaviensis SCHLAGINTWEIT.

Acknowledgements. The thin sections on which the present study is based were kindly provided by Diethard Sanders (University of Innsbruck, Austria). Dr. Ioan I. Bucur and an anonymous reviewers are kindly acknowledged.

\section{R E F E R E N C E S}

Elliott, G.F. 1955, The Permian alga Gymnocodium. Micropaleontology, 1 (1): 83-90.

Elliott, G.F. 1956, Galaxaura (calcareous algae) and similar fossil genera. Journal of the Washington Academy of Sciences, 46 (11): 341-342.

Elliott, G.F. 1958, Algal-debris facies in the Cretaceous of the Middle East. Palaeontology, 1 (3): 254-259.

Elliott, G.F. 1959, New calcareous algae from the Cretaceous of Iraq. Revue de Micropaléontologie, 1 (4): 217-222.

Kochansky-Devidé, V., Slisković, T. 1968, Oberpermische Mikrofossilien von Han Orahovica und Suljci in Bosnien mit besonderer Berücksichtigung der Alge Permocalculus fragilis. Geologia Vjesnik, 22: 105-110.

Radoičić, R. 2004, Permocalculus nikolapantici n. sp. (Udoteaceae?) from the Upper Turonian of the NW Serbia. Bulletin, Classe de Sciences Mathématiques et Naturelles, Sciences Naturelles, 42: 237-257.

Roux, A., Deloffre, R. 1990, Révision des Gymnocodiaceae (algues rouges, Permien - Crétacé). Taxonomie, Biostratigraphie, Paléobiogeographie. $1^{\text {re }}$ partie: Géneralités sur la famille. Revue de Micropaléontology, 33 (2): 123-137.

Sanders, D. 1998, Tectonically controlled Late Cretaceous terrestrial to neritic deposition, Gosau Group, Northern Calcareous Alps (Tyrol, Austria). Facies, 39: 139-178.

Schlagintweit, F. 1991, On the occurrence of the genus Permocalculus ELLIOTT, 1955 (Calcareous algae, Gymnocodiaceae) in the Upper Cretaceous of the Northern Calcareous Alps (Branderfleck Formation, Gosau Formation) with the description of Permocalculus gosaviensis n. sp. Revue de Paléobiologie, 10: 37-46. 
Plate 1. Permocalculus gosaviensis SCHLAGINTWEIT from the Lower Gosau Subgroup of the Brandenberg area, Tyrol, Austria.

Fig. 1. Wackestone with scattered algal debris (Thin section 5495-12; scale bar $1 \mathrm{~mm}$ ).

Fig. 2. Tangential-oblique section (Thin section 5495-10; scale bar $0.5 \mathrm{~mm}$ ).

Fig. 3. Fragmentary longitudinal section showing repeated branching of the cortical filaments; only the last order filaments tend to accommodate in an orthogonal position towards the thallus surface, others are obliquely arranged (Thin section 5495-12; scale bar 0.5 mm).

Figs. 4-6. Longitudinal sections showing the constrictions of the thalli (waxing-and-waning type, sensu Elliott, 1959). Note thallus branching in Fig. 5. In all specimens shown the medullary filaments are not preserved and the hollow is filled with sediment (Thin sections 16995-7, 16995, 17995-2; scale bars $0.5 \mathrm{~mm}$ ).

Figs. 7-9, 13. Longitudinal-oblique sections showing preserved medullary filaments. Note ovoid micritic bodies (arrow, ? reproductive organs, ? borings) in Figs. 7, 8. Fig. 13 represents an excerpt from Fig. 1 (Thin section 5495-12; scale bars $0.5 \mathrm{~mm}$ ).

Fig. 10. Oblique longitudinal section of waxing and waning segment (Thin section 5495-10; scale bar $1 \mathrm{~mm}$ ).

Figs. 11-12, 14. Oblique transverse sections (Thin section 5495-12; scale bars $0.5 \mathrm{~mm}$ ). 
PLATE I
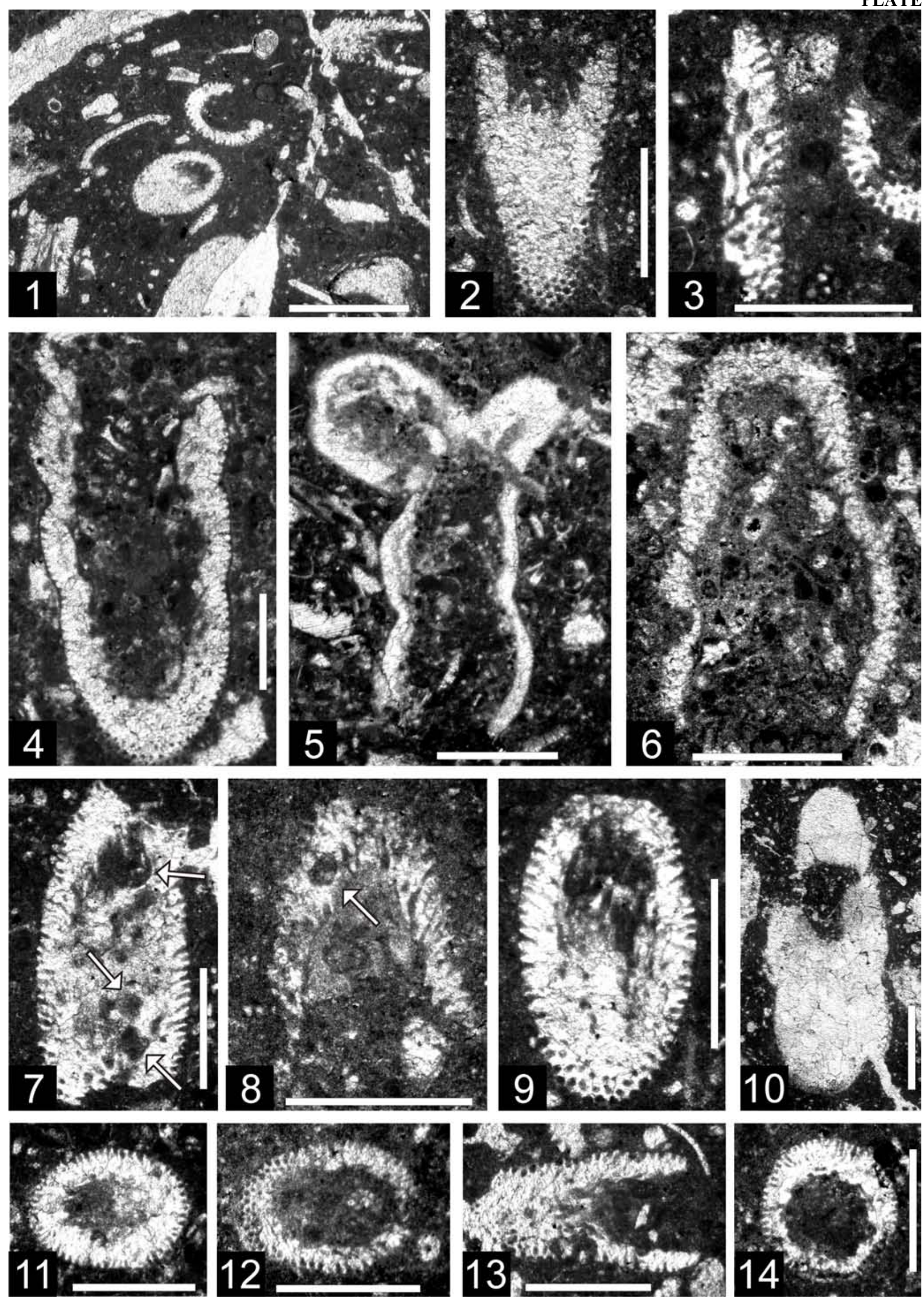
Plate 2. Permocalculus gosaviensis SCHLAGINTWEIT from the Lower Gosau Subgroup of the Brandenberg area, Tyrol, Austria and some accompanying dasycladalean algae (Figs. 3, 11, and 12).

Figs. 1, 2, 5. Oblique sections (Thin sections 5495-12; scale bars $0.5 \mathrm{~mm}$ ).

Fig. 3. Oblique transverse sections of Permocalculus gosaviensis SCHLAGINTWEIT on the left and dasycladalean alga Milanovicella hammudai (RADOIČIĆ) on the right (Thin section 5495-10; scale bar $1 \mathrm{~mm}$ ).

Fig. 4. Fragmentary longitudinal section with preserved medullary filaments (Thin section 5495-12; scale bar 0.5 mm) (Excerpt from Pl. I, Fig. 1).

Fig. 6. Longitudinal-tangential section (Thin section 5495-12; scale bar $0.5 \mathrm{~mm}$ ).

Figs. 7-10. Transverse sections, some partly oblique. Note different state of filament preservation. Fig. 9 represents an excerpt from P1. I. Fig. 1 (Thin section 5495-12; scale bars $0.5 \mathrm{~mm}$ ).

Fig. 8. Two oblique sections (Thin section 5495-12; scale bar $0.5 \mathrm{~mm}$ ).

Figs. 11-12. Dasycladale Cylindroporella? aff. kochanskyae RADOIČIĆ (Thin sections 5495-12, 19995-19; scale bars 0.5 mm). 

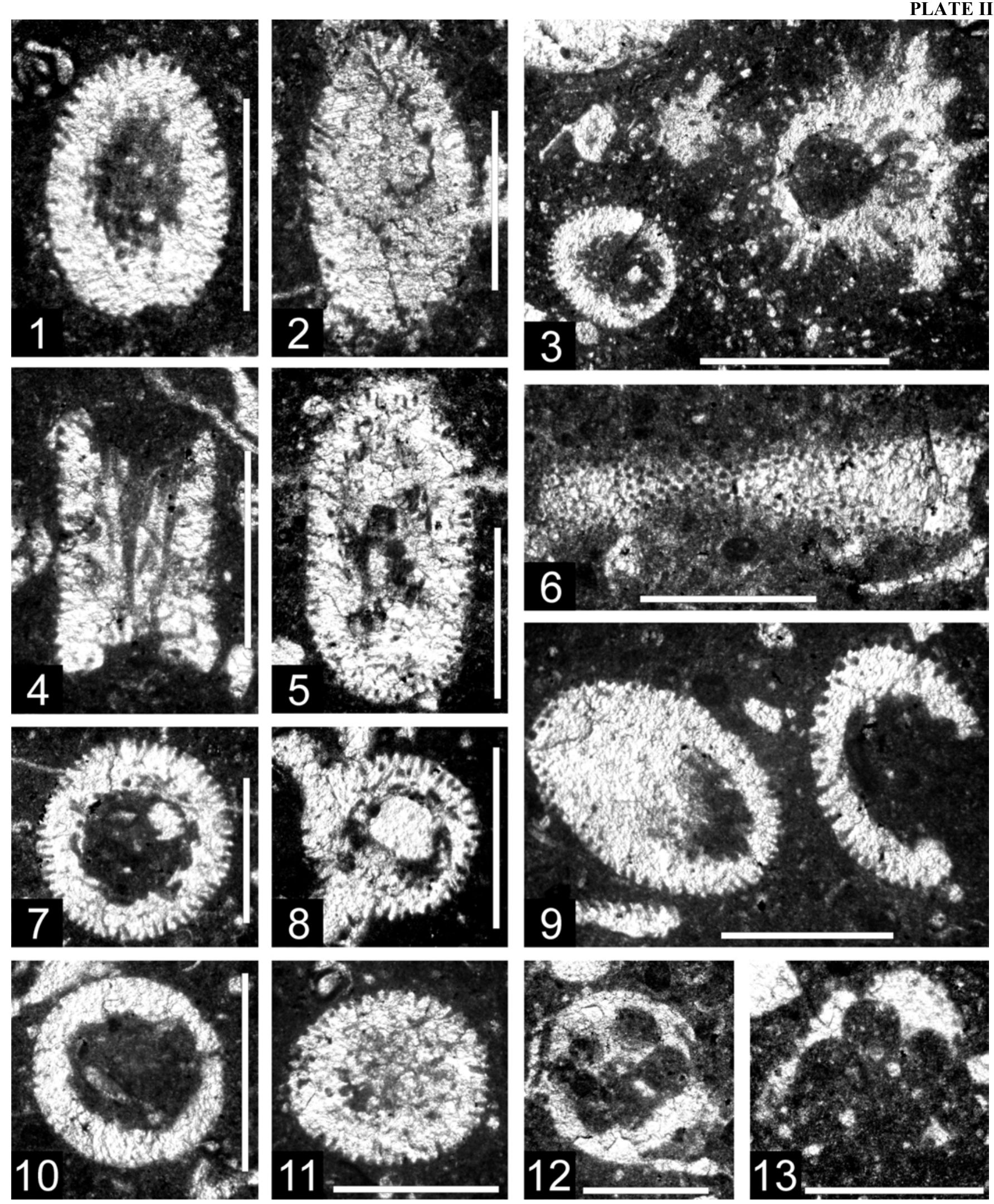